\title{
Native Culture and Literature under Colonialism: Fanon's Theory of Native Resistance and Development
}

\author{
MHD Noor Al-Abbood ${ }^{1}$ \\ ${ }^{1}$ Department of Foreign Languages, Taif University, Taif, Saudi Arabia \\ Correspondence: MHD Noor Al-Abbood, Department of Foreign Languages, Taif University, Taif, Saudi Arabia. \\ Tel: 966-58-287-1671. E-mail: noorabd@yahoo.co.uk
}

Received: January 26, 2012

Accepted: June 19, 2012 Online Published: August 21, 2012

doi:10.5539/ells.v2n3p121

URL: http://dx.doi.org/10.5539/ells.v2n3p121

\begin{abstract}
This article provides a critique of Fanon's three-stage narrative of native literary and cultural development. Fanon envisions a "stage-ist" narrative of native culture and literature moving teleologically from a moment of total identification with the colonizers to a moment of total freedom, through an ambivalent stage of nativist resistance. The main question this article addresses is: can we take this narrative, with its explicit and implicit theoretical assumptions, as a paradigm of native cultural and literary anti-colonialism? My argument is that such a narrative does indeed provide indispensable insights in illuminating specific moments or in critically explaining certain themes in the native culture of opposition. Fanon shows acute understanding of the salient issues relating to nationalism and nativism, their constructions of identity and of the past, and their relationship to the West in general. I have nevertheless found that this narrative cannot be upheld as paradigmatic of the colonial experience as such. For it is implicitly premised on the Caribbean colonial experience which is particular enough not to be generalized. The limitations of Fanon's views, which underestimate the vitality and power of native culture, stem from his conception of colonial power as absolute, at least at the early stage of the colonial relationship. This conception of colonial power as total does not, however, take into account the various ways in which this power has been exercised and resisted at different times and in different places.
\end{abstract}

Keywords: Frantz Fanon, colonialism, resistance, native culture, native literature, post-colonial theory

\section{Introduction}

Tracing the works of the native writers, Frantz Fanon (1967) claims that it is possible to envision a three-phase narrative, or "a panorama on three levels" (p.178). In the first stage, which he calls as the "period of unqualified assimilation", the colonized native writer's literary production shows that he is completely assimilated into the culture of the colonizer. This literary output is European-inspired and imitative of the literary trends and intellectual fashions of the metropolis. The native intellectual "has thrown himself greedily upon Western culture" (Fanon, 1967, p.176). The tendency to follow metropolitan aesthetic and cultural trends is manifested, according to Fanon, in the emergence in peripheral literatures, of Parnassian, symbolist and surrealist fiction and poetry (p.179). At this stage the native writers' identification with the colonizing culture is total: "[t]heir writings correspond point by point with those of their respective numbers in the mother country" (pp.178-179).

The second stage is envisioned as the dialectical antithesis of the first phase. It occurs just before the start of the anti-colonial battle, that is, just before the emergence of a fully conscious and concerted decolonizing force in the colony. Characteristic of the literature produced during this phase, argues Fanon, is the re-narration or re-interpretation of past times and old legends "in the light of a borrowed aestheticism and a conception of the world which was discovered under other skies". Here the native writer starts "to remember what he is" and to (re)turn to his people. He remains, however, unable to fully participate in or reflect the lived experience of his people insofar as he has only a superficial and "exterior relation" with them. In fact, Fanon goes on to say, the native writer at this stage does not go beyond "recalling" the life of his people. The third phase marks the emergence of a national, fighting and revolutionary literature. If the native writer tried in the previous stage to live in the past of his people, he now "turns himself into an awakener of the people." Joining the masses in their national liberation movement, the native writer now will not be able only "to compose the sentence which expresses the heart of his people," but he will also become "the mouthpiece of a new reality in action" (p.179).

This is basically the narrative of native literary and intellectual development that Fanon constructs. However, as 
Patrick Williams and Laura Chrisman (1993) have suggested, Fanon's model of intellectual development in the colonial context is inadequate since it cannot thoroughly and adequately account for the constitution of the subjectivity of these intellectuals. Williams and Chrisman therefore call for "an historical theorization of these intellectuals as crucial exponents of anti-colonial subjectivity, one which goes beyond Fanon's highly teleological and progressivist 'three stages' characterization of anti-colonial intellectual development" (p.15). Indeed Fanon's model is highly problematic, and there is a need for the sort of theorization that Williams and Chrisman call for. In what follows I shall make a modest attempt in this direction, limiting myself only to a critique of Fanon's narrative of colonial literary and intellectual development. To delimit the scope of this article even further, I must state at the very outset that I do not intend to supplant Fanon's narrative by one of my own, for part of the point I shall raise against Fanon is the impossibility of constructing such an abstract narrative. Another point that I should like to stress here is that this article is concerned with the theoretical problems that his model raises (or illuminates), rather than simply with reading a particular author or text in relation to this model. There have been interesting attempts at reading particular literary texts, authors or literary histories through Fanon. The work of Neil Lazarus and Patrick Taylor is so far the best in this regard (Taylor, 1989; Lazarus, 1990; Irele, 1969; Neill, 1982; Tabuteau, 1993; Patil, 1995; Fusco, 1995; Agovi, 1990; Richards, 2005). To study a specific literary theory means to interrogate its categories and underlying ideological assumptions. Placing Fanon's paradigm within the totality of his work, this article will question its internal logic and how it relates to the rest of his work. Nevertheless, in order to profitably evaluate his literary theory and criticism, there will be a need to look at the history of colonial literatures and cultures to be able to gauge how far his proposed model can be related.

\section{The Early Stage: in the Beginning There Were Only Mimic Men}

One of the problems of the paradigm Fanon proposes is the fact that it is too cryptic, with extremely little details of the three phases he identifies. Obviously in this schema he intends to describe the intellectual and political performance of the native elites. It seems to me, however, that his thinking here reflects more or less his thinking about native culture under colonialism in general. In order to understand the complexity of this paradigm, we need therefore to look at his entire work, where on many occasions he raises the question of colonial influence on native culture, and in turn the resistance of such culture to the dynamics and effects of colonialism. The first striking feature of the literature of the first phase of this paradigm, Fanon claims, is that the native writer totally identifies with the culture of the colonizer aesthetically and ideologically. For not only are Western literary forms reproduced, but even the content of such literature reflects Western colonial attitudes and cultural practices. In the absence of further details, we can only surmise that Fanon's characterization of this first phase reflects his early research and conclusions in Black Skin, White Masks and in his essay "West Indians and North Africans," which is reprinted in Toward the African Revolution. In "West Indians and North Africans" he remarks that before Aimé Césaire's "West India literature was a literature of Europeans:"

Until 1939 the West Indian lived, thought, dreamt, composed poems, wrote novels exactly as a white man would have done ...The West Indian identified himself with the white man, adopted a white man's attitude, and "was a white man." (1969, p.26)

These remarks are adumbrated in Black Skin, White Masks. The thrust of the argument of this text is that the internalization of colonial culture, with its racist representation of the black other, induces a self-division in the black subject (1986, p.17). Fanon's colonial "Negro," as Stuart Hall (1996) puts it, "is obliged, in the scenarios of the colonial relation, to have a relation to self, to give a performance to self, which is scripted by the colonizer," producing in him the internally divided, pathological condition of self-hatred and alienation (p.18). The concept of "black skin, white masks" then is not only meant to explain the black subject-constitution, but also the attendant psychopathologies of this split identity. Fanon seems thus to imply this argument in his description of the early "assimilationist" period.

However, turning the concept of "black skins, white masks" without adjustment into a general theory of subject-constitution applicable to allnative intellectuals in the early phases of colonialism raises many questions about the validity of Fanon's claims. Surely not all colonial subjects are black, nor have all the black colonial subjects been subjected to the same colonial conditions as the Afro-Caribbeans. For the Afro-Caribbean social formations are, after all, particular cases. As Vere Knight (1994) points out, most of the islands were colonized by France, "which sought not merely political and economic domination, but, in the most active of fashions, cultural [hegemony] as well" (p.548). This colonial project "found Antilleans especially vulnerable because they lacked the support systems available to other colonized peoples - for example, in Africa - since they had been uprooted from their original homeland" and brought to the Caribbean "in a condition of slavery" (p.548). Octave Mannoni (1956), whose psychological study of colonialism appeared before that of Fanon, observes that 
"[a]ssimilation can succeed if the personality of the native is first destroyed through uprooting, enslavement, and the collapse of the social structure, and this is in fact, what happened - with debatable success, however - in the 'older' colonies" (p.27). In this regard, the theoretical power of Fanon's concept of "black skin, white masks" derives in part from its ability to historicize the particular experience of Afro-Caribbean colonial formations. In the introduction to Black Skin, White Masks, he makes it clear that this study is concerned with the Antillean, middle class, assimilated intellectuals. "My observations and my conclusions," he writes, "are valid only for the Antilles - at least concerning the black man at home" (1986, p.16). At the end of the same book he reinforces the fact that "[i]ntellectual alienation is a creation of middle-class society" (p.224). He also emphasizes the "temporal" dimensions of Black Skin, White Masks, and that he is concerned specifically with his own people, his own country and his own times (pp.14-15).Unfortunately, this nuanced sense of historicity is lost in his later generalized claim in The Wretched of the Earth that all early native writers - Caribbean and otherwise - are entirely lost in the culture of the colonizer. For although the focus of his analysis shifts from the Caribbean to Algeria, to Africa and the Third World at large, he continues to view the colonial situation and the narrative of literary and cultural development through the same Afro-Caribbean lenses. As Knight (1994) argues, Fanon "attempts to show the dynamics of a situation that he holds as illustrative and then attempts to generalize." This pushes him to impose a post hoc analysis on situations that are not exactly identical with his starting point (p.556; Patke, 2001, p.164). David Caute (1970) has also pointed out this problem of Fanon's schematic presentation in terms of its application to African realities. Caute rightly argues that "what is particularly noticeable in the case of Fanon is how his West Indian background ... results in an abstract view which ignores variables of African development." The Martinican in him "ignores the complicating impact of local African languages both oral and written" (pp.30-31).

As far as colonial literatures are concerned, Caute points out, early "apprentice" literature that is supposed to be, according to Fanon, subservient to the colonizers, "does not always involve assimilation of the occupying culture and language". Caute argues that Southern Bantu early literature is "generally expressed in local languages and based on oral traditions of story-telling" (p.31). Moreover, writing in the colonial language is not of itself an evidence of pro-colonial attitudes and sensibility, since as Caute also reinforces, "a good deal of early protest literature was articulated in European languages" (p.31). In the Maghreb, for example, the first significant writers to write in French expressed, as Albert Hourani (1991) points out, "a specific sensibility and mode of thought". In Algeria, writers such as Kateb Yacine (1929-1989), Mouloud Feraoun (1913-1962) and Mouloud Mammeri (1917-1988) "used their mastery of French to explore problems of personal liberation and national identity." As Hourani goes on to explain, that these writers wrote in French "did not mean that they were torn from their roots; it was a result of their education and the position of their communities; some of the Algerians were Berbers from Kabylia who were more at home in French than in Arabic" (p.397). Again, as Caute (1970) also points out, "an African writer like Ephraim Amu of the Gold Coast could rally his countrymen against the [European] invader[s] in his native Turi, an option [simply] not available to the writers of the Caribbean, who were at that time engaged in both perfecting and fragmenting the French language in the service of a somewhat artificial and exotic ideology of negritude" (p. 31).

The above remarks lead us to the probably most striking feature of Fanon's paradigm: namely, what Mpalive-Hangson Msiska (1997) has called in a related context, the "teleological conception of history" in which native literatures "are seen as progressively moving from an initial moment of absolute colonial control ... to one of absolute autonomy in the post-colonial era" (p.47). Indeed there is in Fanon, as Homi Bhabha has recently written, a "teleological belief that the whole process would end in a new humanism, a new ... freedom" (Bhabha, 2004). However, such teleological conceptions as Fanon's raise many questions. The first important one involves the nature of colonial discourse and intentionality. I $n$ the first instance, as Mpalive-Hangson (1997) argues, tore present colonial hegemony in the past as absolute is to disregard "the co-presence of colonized as well as autonomous spaces in each phase of the development of the [native] literature". In the second instance, "to regard the writers, the texts and the literary institutions of the [early 'assimilationist'] period simply as effects of colonial ideology is to accept uncritically that colonial ideological intentionality was always true of colonial ideological practice, which was never the case" (p.49, p.62). What is meant here is that the ideological effects on natives that the colonizers sought to establish did not always materialize according to their intentions. This is one reason why colonial control can never be total, and why colonial authority is always potentially open to subversion (Al-Abbood, 2005; 2006). From a related perspective, Terry Eagleton has taught us that although literature undoubtedly colludes in reproducing the dominant ideologies of society, it cannot be described as always and entirely reflective of these ideologies. Similarly, literary texts cannot be understood wholly by reference to "authorial intention" whether the authors are explicitly or unconsciously ideologically partisan (1976, p.20, p.36, p.37, p.58; 1983, pp.6790, p.120, p.179). From this perspective, Fanon's paradigm seems to 
problematically conceive of literature as simply a passive mechanistic reflection, inertly registering social and ideological development.

As in the examples of Caute and Hourani, one can empirically muster any number of examples to contradict this paradigm, not only at the level of the history of native literatures but also at the level of individual writers. Theoretically speaking, however, colonial policies of assimilation can be shown to produce just the sort of "evolvés" or "mimic men" who would pose a challenge to colonial authority, a fact that makes concepts such as "total assimilation" impossible. Homi Bhabha (1994) has illuminated this process, which he calls "mimicry" and "hybridity." For Bhabha the colonizer intends to transform (civilize) the natives by forcing them to adopt (assimilate, mimic) the values and norms of Western culture, an intention that sums up the goal of the colonial "civilizing mission." However, the discourse of the civilizing mission is ambivalent since the native subject is seen contradictorily as both open to the possibility of reformation and assimilation into Western colonial culture, and as ontologically different and inferior. Mimicry represents, therefore, an "ironic compromise ... the desire for a reformed, recognizable other, as a subject of a difference that is almost the same, but not quite. Which is to say, that the discourse of mimicry is constructed around an ambivalence; in order to be effective, mimicry must continually produce its slippage, its excess, its difference" (p.86). However, it is precisely this ambivalence that makes mimicry for Bhabha "one of the most elusive and effective strategies of colonial power and knowledge" (p.85). It is effective because colonial control depends mainly on the differentiation that the strategy of mimicry requires between, for example, being English and being "Anglicised". It is elusive, however, because this differentiation contains and subverts the colonizer's "civilizing mission."

In certain respects at least, Bhabha's concepts of mimicry and hybridity can be seen as similar to Fanon's concept of "blackskin/white masks." However, it is in seeing the consequences of mimicry as always productive and empowering that Bhabha differs from Fanon. For Fanon the effect of this strategy remains unidirectional, that is, as a colonial means of native social and political control. However, for Bhabha, notwithstanding the assimilationist, civilizing "intention" of the colonizer, mimicry produces new native subjects whose "difference" distorts and subverts the identity of the colonizing subject by "rearticulating its presence in terms of its 'otherness', that which it disavows" (p.91). In a sense, "translating" the terms of colonial discourse into native idioms produces new forms of knowledge and subjectivity unforeseeable for colonial power, which can be therefore disruptive and transformative (Mullaney, 2010, p.31, p.120). In contrast, Fanon does not conceive of the native as being able to estrange or undermine the colonial script when performing the scenario written by the colonizer. In short, if in Fanon's writings colonial authority establishes its hegemony by inducing black subjects to mimic the colonizer's culture (1986, pp.17-18), in Bhabha's work the uncontrollable effects of this strategy itself undermine the operation of colonial knowledge/power; whereas Fanon's black mimics are dislocated subjects who need to be emancipated from colonial culture, Bhabha's mimic men positively, even if unconsciously and unintentionally, undermine colonial authority.

Now let us broach Fanon's paradigm from a different angle. That his narrative should begin in the colonial era, and that it should identify the early native intellectual as completely lost in the culture of the West, casts light on Fanon's flirting with the view, common to some postcolonial theorists such as Spivak (1988), that the epistemic and literal violence of colonialism has induced a more or less total rupture in the colonized culture such that any link with pre-colonial forms of culture has been severed or mutated beyond recovery. In her reading of Fanon's narrative, SuhaSabbagh (1982) argues that for him a complete or "near total annihilation of indigenous culture, in what includes indigenous literary traditions, takes place in the first phase" (p.124). Similarly, Neil Lazarus (1993) contends that Fanon constructs "colonialism as a total and elemental rupture within African history ... [his] thinking about colonial culture is premised upon a preliminary assumption as to the decisiveness of the transformation wrought by colonialism, such that scarcely anything of pre-colonial African culture is seen to survive into the colonial era" (p.74, pp.76-77). These observations by Sabbagh and Lazarus precisely capture Fanon's argument, especially with regard to his narrative of native development. Indeed colonialism is, at times, represented by him as utterly destructive of pre-colonial culture. In Black Skin, White Masks he argues pessimistically that

[o]vernight the Negro has been given two frames of reference within which he has had to place himself. His metaphysics, or, less pretentiously, his customs and the sources on which they were based, were wiped out because they were in conflict with a civilization that he did not know and that imposed itself on him. (1986, p.110)

Although Fanon is speaking here of two frames of reference, his polemic presents only one, that is the Western culture which is imposed on the natives. As is clear here, he sees colonization as total and insists that native traditions were suddenly and totally obliterated. This conception is then used, as Lazarus (1993) points out, "to 
ground a definition of the experience of colonization" (p.74). A colonized people, Fanon (1986) writes, are one "in whose soul an inferiority complex has been created by the death and burial of its cultural originality" (p.18).

However, the idea that a "total rupture" in native culture has occurred is not only empirically indefensible, but also logically incoherent. If native cultural resources survive intact, why then is there a need to combat colonialism? Conversely, if native cultural resources have been totally destroyed, how can the native resist colonialism? The first position flatters the native culture only at the price of letting the colonizers off the hook; the second case indicts colonial power strongly but ineffectually. The case is that, as Lazarus (1993) argues, at least "some pre-colonial cultural and ideological forms [have] survived meaningfully, often intact, and in some instances entirely unaffected, not only into, but also through, the colonial era." Indeed, adds Lazarus, "they continue to survive meaningfully today, in the 'postcolonial' present" (p.77). Many African writers would likewise maintain that "the African has not been completely severed from his roots" (WaThiong'o, 1972, p.41). The Afro-Caribbean novelist George Lamming (1960) affirms that "the African, in spite of his modernity, has never been wholly severed from the cradle of a continuous culture" (p.34). Similarly, Amilcar Cabral (1973) argues that "[w]ith certain exceptions, the period of colonization was not long enough, at least in Africa, for there to be a significant degree of destruction or damage of the most important facets of the culture and traditions of the subject people" (p.60).

Moreover, contrary to Fanon's problematic pronouncements, some new research shows that colonialism, rather than destroying native traditions, in most cases reinforced them. Of course, it did so not for any humanitarian reason but to facilitate economic and political control. Dennis Walder (1998) argues that in the aftermath of the 1857 Indian Rising, a new, more effective system of administration as "indirect rule" was introduced. The Indian "feudal princes who had supported the status quo during the rising became puppet rulers of 'independent' states." This was

a development that became a hallmark of this phase of British imperialism, especially in tropical Africa where, as "indirect rule", it allowed a handful of Britons to administer the lives of millions of natives through their traditional chiefs. Lord Lugard, who introduced the system into Africa on the basis of his experience as a soldier in India, saw it as a way of bringing firm and impartial rule while respecting local customs and traditions. (p.36)

This is also the view of Ania Loomba (1998) who points out that colonial administration of India "functioned to a large extent through local authorities and existing power structures." As such, it often reinforced rather than disturbed "native hierarchies" (p.111).

From another perspective, studying the literature on madness in colonial Africa, Megan Vaughan (1991) argues that it was believed by colonialists that the "deculturation" brought about by the "disintegration" of "traditional" structures and the strains of modernization, was the cause of rising insanity among Africans who were unable to cope up with "the disruptive changes wrought by colonialism and capitalism" (p.109).This process raised colonial fears of loss of "social control" (notice the inversion of Bhabha's mimicry model). The political solution that colonialist functionaries envisaged was "a system of indirect rule," so that Africans could be ruled by their own "traditional" leaders and according to their own "traditional" norms. "It was especially important," Vaughan writes, "that Africans experiencing the upheavals of industrialization should know who they were, that they should retain a cultural identity (expressed in terms of belonging to a specific "tribe" with its distinctive customs)" (p.109).

Here it is worth stressing Dennis Walder's contention that at its best, "indirect rule" "minimizes" the impact of colonialism, although the overall effects of this regime are not far less negative than a direct colonial intervention in the culture of the natives. For "it also helped to preserve the conservative social order of the past with all its inequities" (1998, p.36). Similarly Loomba avers that for those "[m]illions of Indians [who] never saw an English person throughout the term of the Raj," and for whom colonial authority invariably "wore a native face," this regime of indirect rule "did not mean that their lives had not been woven into the fabric of empire" (p.179). In addition to the reminder of Walder and Loomba about the insidious effects of indirect colonial rule, we should perhaps warn that the view that colonialism completely destroyed native pre-colonial culture must not be simply replaced by another affirming an unproblematic survival of this culture. One has to take cognizance of what Ashis Nandy (1983) describes as colonialism's “ability to create secular hierarchies incompatible with the traditional order" (p.ix). In his excellent psychoanalytical study of Indian traditions under colonialism, Nandy argues that even when traditions survive, they emerge "less innocent from the colonial experience" (p.xvi). For colonialism "releases forces within the colonized societies" that "alter their cultural priorities once and for all" (p.xi). For instance, it "bring[s] to the centre of the colonial culture subcultures previously recessive or subordinate." Concurrently, it removes "from the centre" of the native culture "subcultures previously salient" in 
it (p.2).

As I have pointed out, although Fanon at times holds that colonialism is totally destructive of native culture, it must be stressed that he does not sustain this view throughout. Nor can the totality of his work be understood in the light of such an assumption. For how can we otherwise understand his repeated emphasis that "[a] national culture under colonial domination is a contested culture whose destruction is sought in systematic fashion" (1990, p.191), or that the native intellectuals are able to return to the culture of their people at some stage of development, without assuming the prior existence of such a culture? Fanon makes sometimes contradictory statements that cancel each other out, a fact that frustrates any attempt to present formally and unequivocally his theories in this regard. In "Racism and Culture," for example, he argues that the setting up of the colonial system does not of itself bring about the death of the native culture; the aim sought is a "continued agony rather than a total disappearance of the pre-existing culture" $(1969$, p.34). It is not entirely clear what he means by "agony", but he probably means "slow, painful death." For the thrust of the argument of this essay is that colonialism prevents the native culture from freely developing as it would without the constraints imposed by the colonizers. Ironically, here he is in partial agreement with Walder and Loomba: colonialism is indicted not for totally obliterating native culture, but, on the contrary, for freezing it, thereby preventing it from evolving to a degree of contemporaneity to meet the needs of a naturally developing society.

Nevertheless, his narrative dramatically inflates the power and authority of the colonial order such that, at least in its conception of the earlier stage, it writes off any evidence of dissension or resistance on the part of the native masses or their intellectuals. Native culture, if not destroyed, is inert and lacking in vitality. This view is not complicit, as some might prematurely deem, with the ideological premises of Eurocentric constructions of the native as essentially supine and inert, hence "the myth of the lazy native." Fanon (1969), on the contrary, denounces "[t]he reproach of inertia constantly directed at "the native'[as] utterly dishonest" (p.34). The native is not essentially inert or lethargic. Rather, it is the colonial regime that, as he time and again avers, condemns the native to inertia and immobility. His starting premise is that the colonial order "calls a halt to national culture in almost every field" (1967, p.191). "Racism and Culture" spills out this premise as follows:

This culture, once living and open to the future, becomes closed, fixed in the colonial status, caught in the yoke of oppression. Both present and mummified ... [i]t leads to a mummification of individual thinking. The apathy so universally noted among colonial peoples is but the logical consequence of this operation. (1969, p.34)

Native culture, because it is prevented by colonialism from freely developing, becomes no more than "archaic, inert institutions, functioning under the oppressor's supervision and patterned like a caricature of formerly fertile institutions." If, as Fanon maintains throughout, "[t]he characteristic of a culture is to be open, permeated by spontaneous, generous, fertile lines of force", how is it "possible for a man to evolve" within the framework of colonially imposed cultural structures? (p.34). "The lines of force, having crumbled, no longer give direction" (p.33).

Some of what Fanon says here is unequivocally true. Colonialism in some sense prevents native history from happening, just as it is the very history that is happening to the natives (Eagleton, 1998, p.128). This is what Amilcar Cabral (1974) meant when he accentuated the conditioning and determining influence of colonialism and imperialism on the very shape of African social formations. "We consider," he writes, "that when imperialism arrived in Guinea it made us leave history - our history. ..., and enter another history. .... [T] his gives a completely different aspect to the historical evolution of our country (my emphasis)" (p.56). Yet there is perhaps in Fanon's argument here the myth of the Fall-that before colonialism native cultures were unequivocally dynamic, but with the arrival of the colonizers everything came to a halt. Why should they have been? Maybe they were vital in some ways and inert in others, just like most cultures.

In so formulating the early colonial encounter, Fanon practically speaking discounts, as we have just noted, the early, if often unsuccessful, resistance to imperialism, as he limits the capacity of the colonized to launch a fighting liberationist culture to a later, third stage when "the native decides to put an end to the history of colonization - the history of pillage - and to bring into existence the history of the nation - the history of decolonization" (1990, p.40). Unfortunately, this thesis does not draw inspiration from an earlier form of resistance embodied by such great figures as the Emir Abdel Kader of Algeria or Toussaint L'Ouverture of Haiti, the examples being closer to Fanon's context. Edward Said (1994), whose own narrative of resistance and liberation draws on Fanon's, calls attention to those earlier forms of resistance - what he describes as the period of primary resistance - while agreeing with Fanon on the conception of a third liberationist stage when efforts are made to reconstitute a colonially shattered community (p.252). As Said points out, nearly everywhere in the non-European world, the coming of the "white man" brought forth some sort of resistance: 
Right across the non-European world there had been earlier uprisings, from the San Domingo revolution and the Abdel Kader insurrection to the 1857 Rebellion, the Orabi Revolt, and the Boxer Rebellion. There had been reprisals, changes of regime, causes célèbres, debates, reforms and reappraisals ... The new situation was a sustained confrontation of, and systematic resistance to, the Empire as West. (p.236)

Moreover, Said argues, "this massive political, economic and military resistance was carried forward and informed by an actively provocative and challenging culture of resistance ... with a long tradition of integrity and power in its own right, not simply a belated reactive response to Western imperialism" (p.268). The need to trace these forms of resistance is politically, culturally and historically crucial for the colonizer as well as the colonized. "For the successful nationalist parties that led the struggle against the European powers," Said writes, "legitimacy and cultural primacy depend on their asserting an unbroken continuity" back "to the first warriors who stood against the intrusive white man" (p.238). On another level, Terence Ranger (1968) has shown that many early resistances, even though doomed, "shaped the environment in which later politics developed." They had "profound effects" upon colonial "policies and attitudes". In the course of these resistances, there also emerged "types of political organization ... which looked in important ways to the future; which in some cases are directly and in others indirectly linked with later manifestations of African opposition" (p.631).

Now it is not the case that Fanon does not acknowledge the historical occurrence and importance of these "primary" or early resistances. Rather, it is that he fails to incorporate the significance of this continuity of resistance within his overall schema of liberation. Therefore, if confusion may result from some of Fanon's contradictory statements (Valldejuli, 2007, pp.59-60), partial or selective readings tend characteristically to play up particular emphases at the expense of the rest of his work. Christopher Miller's reading, for example, is reductive and, indeed, faulty because it collapses Fanon's critique of native culture under colonialism into what Miller (1991) claims to be a Marxist conception of history which sees "pre-colonial history as no history at all," leaving "no room for local knowledge" (p.50). Such an argument does not in fact do sufficient justice to Fanon's complex, multivalent analysis, which combines an understanding of the importance of tradition with a relentless critique of the fetishization of the past and of tradition that is characteristic of many forms of nationalism and nativism. For hecandidly, although again not sufficiently, acknowledges the achievements of the preceding generations in both resisting "the work of erosion carried out by colonialism" and in helping on "the maturing of the struggles of today" (1967, p.166). He also values tradition in the early colonial period as a technique of resistance, however passive (p.181). He further admits that only uninterrupted continuities can recover the lost sovereignty of the native subject (C. F. Knippling, 1995, p.252). As such, the native intellectual's claims as regards an uninterrupted continuity with the past "are no luxury but a necessity in any coherent programme" (Fanon, 1967, p.170). Fanon contends that one of colonialism's characteristic strategies is to "distort,"“disfigure" and "destroy" "the past of the oppressed people." Therefore "[t]he claim to a national culture in the past does not only rehabilitate that nation and serve as a justification for the hope of a future national culture."In the sphere of psycho-affective equilibrium, it is responsible for an important change in the native". (p.169)

\section{The Second Stage: The Nativist Revolt and the Invention of Tradition}

This understanding of the importance of the past is simultaneously juxtaposed with the view that the attempt to recover the oldest and most pre-colonial forms of native life is really fraught with problems. These problems, which Fanon carefully traces, are now the subject of intense debates under the rubrics of nativism and nationalism. Anticipating such postcolonial debates, Fanon argues presciently that a pre-colonial past cannot be recovered without mediation and that, as such, it is more often than not reclaimed through what Knippling (1995) describes in a related context as "the phantasmagoric tropes of a collective nostalgia, fantasy, regression and fetish" (p.252). His objection to this form of nativism is two-fold: first, the pure, pristine past sought is often re-inscribed within a pre-set colonial design; second, the value people attach to tradition changes. Therefore a "preservationist" attitude can hinder rather than foster the people's struggle for emancipation. With regard to the second problem, observing the fact that native traditions act as "safeguards" in the early colonial period, Fanon (1967) argues that when a people undertakes an armed or political struggle against colonialism, the significance of tradition changes. In fact, Fanon goes on to say, traditions may be radically questioned, criticized and condemned (pp.180-190): "[T] he forms of thought and what it feeds on, together with modern techniques of information, language and dress have dialectically reorganized the people's intelligences and ... the constant principles which acted as safeguards during the colonial period are now undergoing extremely radical changes" (p.181). If traditions change to accommodate the needs of the present, and the hopes and aspirations for the future, then a nation must take in its present realities as the start point for a definitive future change. After all, "the truths of a nation are in the first place its realities" (p.181). These realities, however, lie in "that fluctuating movement" which the people "are just giving shape to" (p.183), rather than in a past from which they have 
already emerged. In order to be able to reflect the lived experience of nation, the native writer, Fanon advocates, must catch up "with the same rhythm as the people" (p.188). On the basis of this understanding, Fanon warns that "[t]he desire to attach oneself to tradition or bring abandoned traditions to life again does not only mean going against the current of history but also opposing one's own people" (p.187). Fanon's argument in this regard is analogous to that of Edward Said (1994). Appeals to tradition in this sense are "associated with a past that is no longer recoverable except by denying or somehow downgrading the lived experience of those who, in Aimé Césaire's great phrase, want a place at the rendezvous of victory" (p.29). Explicating this point, Fanon states:

I am ready to concede that on the plane of factual being the past existence of an Aztec civilization does not change anything in the diet of the Mexican peasant of today. I admit that all the proofs of a wonderful Songhai civilization will not change the fact that today the Songhais are under-fed and illiterate, thrown between sky and water with empty heads and empty eyes. (1967, p.168)

I do not want to exalt the past at the expense of my present and future. (1986, p.26)

The Vietnamese who die before the firing squads are not hoping that their sacrifice will bring about the appearance of a past. It is for the sake of the present and of the future that they are willing to die. $(1986, p .227)$

The second problem which Fanon (1967) identifies in the "return to tradition" phenomenon in native literature has to do with the native intellectual's inability to free himself from the categories and assumptions of colonial knowledge. Here Fanon insists that the tradition and the past that the native writer is trying to recover are actually reconstructed "in the light of borrowed aestheticism and a conception of the world which was discovered under other skies" (p.179). As with the general schema Fanon proposes, his statements here are cryptic, and we are left with little knowledge of what he really means by "borrowed aestheticism." For he does not consider any particular text, nor does he discuss any such aesthetic issues as literary form, quality, structure or texture. However, Fanon's implication here is that there is just little progress from the first stage he identifies, since the native artist is still operating within influences from Western (colonial) culture. Not only does the native intellectual fail to realize that he is using techniques and language borrowed from the colonizer in his country, but he also fails to realize that he is working under the influence of colonial Western ideology. Inverting the colonizer/colonized, civilized/primitive, white/black, Western/native dichotomies in favor of the colonized does not free them from the insidious power of colonial representations. On the contrary, the categories of colonial discourse are reasserted at the moment of their disavowal. The native writer's desire to create an authentic tradition by observing the past of his people, reconstitutes, paradoxically, such tradition, such past in the image of some Western institutionalized practice, or in the light of some Western conception. As Robert Young (1990) argues in a related context, nativism idealizes the possibility of recovering a lost past/origin "in all its former plenitude without allowing for the fact that the figure of the lost origin, the 'other' that the colonizer has repressed, has itself been constructed in terms of the colonizer's self-image." In other words, the native subject forms a metonymic mirror image of Europe as sovereign subject-nativist literature simply reproduces the Western fantasies and stereotypes about the native other (p.168). As Fanon (1967) stresses, although the native writer attempts to stamp the tools he is utilizing with a "national" authentic hall-mark, his work remains an example of "exoticism." The culture he wants to foster in his artistic endeavors is often "no more than a stock of particularisms." In fact, instead of attaching himself to the people, "he only catches hold of their outer garments" (p.180). Hence Fanon's condemnation of what Kwame Anthony Appiah (1988) calls the native intellectual's "ersatz populism" - "the fetishistic attitude towards customs, folklore and vernacular traditions" - which makes him even more estranged from the people "he venerates" (p.163). As Fanon (1967) argues, the native artist

sets a high value on the customs, traditions, and the appearance of his people, but his inevitable, painful experience only seems a banal search for exoticism. The sari becomes sacred, and the shoes that come from Paris or Italy are left off in favor of pampooties, while suddenly the language of the ruling power is felt to burn your lips (p.178).

In the same rhetoric of ancestral purity, the native artist turns his back on foreign culture, disavows it and sets out to look for a "true" national culture, setting great store by what he considers to be the "constant principles of national art." However, as we have noted above, by naively opposing Western cultural influence, the native artist ends up unwittingly embracing a Western influence of a different sort - Western stereotypes of the other.

The above observations Fanon makes about the constructions of nationalism and nativism do resonate with us today and show a clear understanding of what Terence Ranger (1983) calls "invented" traditions "as distinct from unconsciously evolving custom" (p.236). As Ranger points out pre-colonial African societies "had certainly valued custom and continuity but custom was loosely defined and infinitely flexible. Custom helped to maintain 
a sense of identity but it also allowed for an adaptation so spontaneous and natural that it was often unperceived" (p.247). However, the British colonialists' own respect for "tradition"“disposed them to look with favor upon what they took to be traditional in Africa." Colonial officers and anthropologists collected, organized and enforced "traditions" (p.212). Ironically, many African intellectuals have accepted these invented traditions as "national mythology" (Appiah, 1988, p.164). However, these traditions, whether invented by the Europeans or by African intellectuals in response, "distorted the past" and became in themselves the new "realities" through which a good deal of the conflict with the West was expressed (Ranger, 1983, p.212). In a manner comparable to that of Ranger, Fanon (1967) argues that native subjectivity is constituted in history and that native identity is flexible - "teeming and perpetually in motion." Behind the native garments, there is "a much more fundamental substance which itself is continually being renewed." In contrast, invented traditions are "no more than a stock of particularisms ... the mummified fragments which because they are static are in fact symbols of negation and outworn contrivances" (p.180). In other words, the inert, already forsaken "cast-offs of thought, its shells and corpses, a knowledge which has been stabilized once and for all" (p.181).

Nevertheless, Fanon once again falls back on generalization. For it is difficult to accept his thesis that all such literature at this intermediary stage is invariably reflective of nativist ideology. Moreover, he once again contradicts himself. Contrary to his earlier presentation of the colonizers as programmatically intent on destroying native culture, or as having objectively liquidated all traces of it, here we begin to see at least some Westerners who are enthusiastic about all that is "native," although they are portrayed, to borrow a relevant phrase from Gayatri Spivak and Robert Young, as those "nativists" struck by "pious guilt or hyperbolic admiration" (Young, 1990, p.168).

From another perspective, Fanon seems here so opposed to any Western influence, as if all such influence were oppressive - which is surely a great simplification. In fact, there are many instances in The Wretched of the Earth where he seems to hold such a militant anti-Westernism in the fashion of some unenlightened, anti-Western nationalists. One reason I have chosen to evaluate his paradigm of native development in relation to the rest of hiswork, is my conviction that the premises underlying this paradigm are also to a large extent the premises of the rest of his work. The rejection of any native cultural artifact that might reflect some Western influence is so pervasive in The Wretched of the Earth. No wonder then that he dismisses the native literary-cultural production of the early colonial period and much of the literature of the intermediate one, which he identifies in his schema. For he concludes The Wretched of the Earth, urging his comrades not to "pay tribute to Europe by creating states, institutions and societies which draw their inspiration from her" (1967, p.254). "European achievements, European techniques and the European style ought no longer to tempt us and to throw us off balance" (p.252). Such an orthodox, puritan view, however, disregards the fact that if the consequences of Western modernity were disastrous for non-Westerners (as well as for some Westerners), Western culture has also been enabling in resisting Western imperialism (Al-Abbood, 2004). Fanon's work itself displays this dialectic. Thus, as Dennis Walder (1998) points out, although the main drive of Fanon's discourse is towards revealing the pathological effects of Western colonial culture on the colonized, particularly on the native elites, "the most potent influences detectable in Fanon's writing are also Western" (pp. 73-74). These writings are, in Benita Parry's words, “an exemplary instance of how Western theory - the work of Hegel and Marx, Freud and Lacan, Nietzsche and Sartre -was requisitioned for a discourse of liberation, which has since returned as an indispensible text in investigations of heterogeneous systems of institutional and discursive oppression"(1994, p.19)-not least those of Western imperialism. We have also to remember that hybridity and cultural borrowing are in one sense at least both a fact of intellectual life and generally an enabling condition (see Said, 1983). Besides, as Walder (1998) reminds us, "the origins of a theory don't necessarily determine its validity; and, arguably, it is almost impossible to find some notionally pure, authentic, indigenous discourse" (p.74; see also Eagleton, 1996, p.112; Todorov, 1986, p.376). One cannot therefore simply accept Fanon's condemnation or otherwise berating of the native writers who rely on a "borrowed aestheticism and .... a conception of the world which was discovered under other skies".

Similarly, in relation to the critique of nationalism, one has be careful not to condemn all nationalist "inventions;" otherwise one unwittingly subscribes to an inverted from of nativism or puritan fundamentalism. It is true that institutionalizing or foregrounding certain cultural practices that are not originally prominent or even existent in native culture modifies, even sometimes distorts native identity. Nevertheless, one cannot ignore the progressive aspects of this process of invention and its resistance potentialities at certain times in the anti-colonial conflict. Pace Fanon's criticism of "return to tradition" in the name of present realities, one can argue that the return to the past is itself often the "product of a present need, which reshapes rather than simply invokes the past" (Loomba, 1998, p.195). Interestingly, Fanon himself offers a psychological explanation of this need, as we have 
seen. Ania Loomba (1998) reminds us that anti-colonial nationalism's invention of tradition, in the "complex process of contesting as well as appropriating colonialist versions of the past," aims at challenging colonial authority and reinforcing its own (p.196). From a different perspective, we can confidently say that almost all of our political concepts are after all inventions. Fanon himself makes some admirable statements in this regard. "I should constantly remind myself," he writes at the end of Black Skin, White Masks, "that the real leap consists in introducing invention into existence" (1986, p.229). Similarly he writes at the end of The Wretched of the Earth that "if we want humanity to advance a step further, ... then we must invent and we must make discoveries" (1967, p.256) - discoveries, I should add, not least relevant to the question of, in Fanon's own words once again, "who" and "what" we are. Indeed for the colonized, (re)discovering the past is sometimes as revolutionary as discovering the future. For if the return to the past is typically conservative for the colonizer, so it is quite radical for the colonized. Ngugiwa Thiong'o (1972) says something quite to the same effect with respect to capitalism and socialism. "[I]n a capitalist society," he argues, "the past has a romantic glamour: gazing at it, as witness Wordsworth, and D. H. Lawrence, or more recently Yukio Mishima of Japan, is often a means of escaping the present. It is only in a socialist context that a look at yesterday can be meaningful in illuminating today and tomorrow" (p.46).

\section{The Third Stage: National Revolution and Containment}

One last point about Fanon's narrative, namely his conception of third "liberationist" stage of native literature and culture, deserves attention here. However admirable is Fanon's critique of the African writer who is, as Ngugiwa Thiong'o (1972) has also pointed out, "in danger of becoming too fascinated by the yesterday of his people and forgetting the present" (p.44), Fanon in fact often unjustifiably rhapsodizes about the new (post-) colonial "realities" he is describing. In Studies in a Dying Colonialism he advances the thesis that human beings "change at the time that they change the world" $(1989$, p.30). In order to show how the resistant Algerians have changed, Fanon is anxious to indicate that a clear break with the past has taken place. The Algerian struggle against French colonialism "has opened up for [the Algerian people], vistas it never dreamt existed." There can be "no turning back" (p.28). "The old Algeria is dead. All the innocent blood that has flowed onto the national soil has produced a new humanity and no one must fail to recognize this fact" (pp.27-28, my emphasis).This decolonizing process is described as "always a violent phenomenon ... obviously, a program of complete disorder" (Fanon, 1967, p.27). Although the phrase "complete disorder" in this construction sounds awkward (can indeed complete disorder take the decolonized anywhere?), Fanon wants to emphasize that decolonization is positively and progressively a total change from the colonial situation that the natives lived before. After decolonization, there is not only the death of colonialism but also the death of colonized man. For "decolonization is the veritable creation of new men" (p.28). Here Fanon can indeed be accused of messianism in his premature pronouncements of definitive revolutionary change, in Algeria for example (Lazarus, 1990, pp.27-45). Although he is describing here the impact of decolonization on all the natives, this is exactly the revolutionary change in the native intellectual that Fanon implies in what he describes as the "fighting stage." Yet there is an apparent contradiction between his paradigm of intellectual development and his general remarks about the effects of decolonization on the natives. Consider the following statement:

Finally, in the third phase, which is called the fighting phase, the native, after having tried to lose himself in the people and with the people, will on the contrary shake the people. Instead of according the people's lethargy an honored place in his esteem, he turns himself into an awakener of the people; hence comes a fighting literature, a revolutionary literature, and a national literature. (1967, p.179)

Contrary to the previous statements about a definitive revolutionary change in the consciousness of the natives, in this passage we are given the impression that this change has only occurred in the intellectual, while for the rest of "the people" there is hardly any advance. More precisely, if the militant, decolonizing phase has created, as Fanon claims, "new men and women", why do these still need to be awakened from their "lethargy"? We have seen how he wrongly assumes colonial hegemony in the past to be absolute. Now this absolute hegemony of the past is equally problematically replaced with a conception of absolute freedom in the decolonized present. Nevertheless, as Mpalive-Hangson Msiska (1997) argues in a related context, post-colonial cultural production is anything but free from "the determining influence," whether positive or negative, of the West. Moreover, such a conception of history "unwittingly colludes with nationalists" myths of history in which the post-colonial moment is often uncritically regarded as representing the absence of colonial hegemony" (p.62). Speaking of post-colonial times, Chinua Achebe (1975) remarks that "today, things have changed a lot, but it would be foolish to pretend that we have fully recovered from the traumatic effects of our first confrontation with Europe" (p.44). Interestingly, Fanon (1967) himself discusses in details how revolution is vulnerable to containment, how independence can sometimes be no more than a colonialist ploy, and how bourgeois nationalism continues to 
reproduce colonialist dynamics of native ideological demobilization and economic underdevelopment.

Now let me recapitulate on the foregoing discussion that I have so far made of Fanon's three-stage narrative of native literary and cultural development. The main question I have addressed is: to what extent can we take this narrative, with its explicit and implicit theoretical assumptions, as a paradigm of native cultural and literary anti-colonialism? In other words, to what extent is this narrative able to historicize the native consciousness of and reaction to the culture of imperialism? My conclusion is that such a narrative does indeed provide indispensable insights in illuminating specific moments or critically explaining certain themes in the native culture of opposition. Fanon shows acute understanding of the salient issues relating to nationalism and nativism, their constructions of identity and the past, and their relationship to the West in general. I have nevertheless found that this narrative cannot be upheld as paradigmatic of the colonial experience as such. For it is implicitly premised on the Caribbean colonial experience which is, as I have shown, particular enough not to be generalized. Within this frame of understanding, I have explained why Fanon's concept of "black skin, white masks," which is conceived as paradigmatic of the early "assimilationist" stage of literary development, is theoretically more nuanced and powerful in relation to Caribbean literary output than when applied elsewhere. Even so, I have found that neither Fanon's conception of cultural mimicry nor that of Bhabha is in fact adequate.

I have also questioned the assumptions behind Fanon's underestimation of the vitality and power of colonial native culture prior to the final revolutionary movements that would gain independence for the colonized and induce a transformation in their consciousness. The limitation of Fanon's views stems from his conception of colonial power as absolute, at least at the early stage of the colonial relationship. He holds that native culture is, if not destroyed, then certainly prevented by colonialism from natural, spontaneous development. The conception of colonial power as total does not, however, take into account the various ways in which this power has been exercised and resisted at different times and in different places.

\section{References}

Achebe, C. (1975). Morning yet on Creation Day: Essays. London: Heinemann.

Agovi, K. E. (1990). The African Writer and the Phenomenon of the Nation State in Africa. Ufahamu (Los Angeles), 18(1), 41-62.

Al-Abbood, M. N. (2004). Enlightening the Anti-Enlightenment Trends: The Western Humanist Tradition and (Anti) Colonialism. Abhath Al-Yarmouk (Literature and Linguistics Series), 22(2), 179-233.

Al-Abbood, M. N. (2005). Anti-Colonial Nationalism and the West: Towards a Critique of Recent, Western-Based, Anti-Nationalist Scholarship. Dirasat (Human and Social Sciences), 32(1), 213-231.

Al-Abbood, M. N. (2006). Rampant (Colonial) Power, Undertheorised (Native) Resistance: Foucault, Bhabha, Said: An Essay in Memory of Edward Said (1935-2003). Abhath Al-Yarmouk (Literature and Linguistics Series), 24(2), 169-219.

Appiah, K. A. (1988). Out of Africa: Topologies of Nativism. Yale Journal of Criticism, 1(2), 153-178.

Ashcroft, B., Griffiths, G., \& Tiffin, H. (1989). The Empire Writes Back: Theory and Practice in Post-Colonial Literatures. London and New York: Routedge

Bhabha, H. (1994). The Location of Culture. London and New York: Routledge.

Bhabha, H. K. (2004). Foreword: Framing Fanon. In F. Fanon, The Wretched of the Earth (R. Philcox, Trans.) (pp. vii-xli). New York: Grove Press.

Cabral, A. (1973). Return to the Source. New York: Monthly Review.

Caute, D. (1970). Fanon. London: Fontana/Collins.

Eagleton, T. (1976). Marxism and Literary Criticism. London: Methuen \& Co. LTD.

Eagleton, T. (1983). Literary Theory: An Introduction. Oxford: Basil Blackwell.

Eagleton, T. (1996). The Illusions of Postmodernism. Oxford: Blackwell Publishers.

Fanon, F. (1967). The Wretched of the Earth, (C. Farrington, Trans.). London.

Fanon, F. (1969). Toward the African Revolution, (H. Chevalier, Trans.). New York: Grove Press.

Fanon, F. (1986). Black Skin, White Masks, (C. L. Markmann, Trans.). London: Pluto Press.

Fanon, F. (1989). Studies in a Dying Colonialism, (H. Chevalier, Trans.). London: Earthscan Publications Ltd.

Fusco, C. (1995). The Wretched of the Earth: The Ethics of Political Violence and its Ministers of Sacrifice In 
Edward Bond, Jackets. ÉtudesAnglaises, XLVIII(3), 296-305.

Hall, S. (1996). The After-life of Frantz Fanon. In A. Read (Ed.), The Fact of Blackness: Frantz Fanon and Visual Representation (pp.13-37). London: ICA.

Hourani, A. (1991). A History of the Arab Peoples. London: Faber and Faber.

Irele, F. A. (1969). Literature and Ideology in Martinique: René Maran, AiméCésaire, Frantz Fanon. Research Review (Ghana University, Institute of African Studies), 5(3), 1-32.

Knight, V. (1994). Colonialism as Neurosis: Frantz Fanon. In J. Arnold, J. Rodriguez-Luis, \& M. Dash (Eds.), A History of the Caribbean (Vol. 1, pp. 547-558). Amsterdam: John Benjamin's Publishing Company.

Knippling, A. S. (1995). On Empire, Time, History; or What Does the Post- in Post-Colonial Signify? In R. S. Corrington \& J. Seely (Eds.), Semiotics 1993 (pp.249-253). New York: Peter Lang.

Lamming, G. (1960). The Pleasures of Exile. London: Joseph.

Lazarus, N. (1990). Resistance in Postcolonial African Fiction. New Haven and London: Yale University Press.

Lazarus, N. (1993). Disavowing Decolonization: Fanon, Nationalism and the Problematic of Representation in Current Theories of Colonial Discourse. Research in African Literatures, 24 (4), 69-98.

Lazarus, N. (1994). National Consciousness and the Specificity of (Post) colonial Intellectualism. In F. Barker, P. Hulme, \& M. Iversen (Eds.), Colonial Discourse/Postcolonial Theory (pp.197-220). Manchester: Manchester University Press.

Loomba, A. (1998). Colonialism/Postcolonialism. London and New York: Routledge.

Mannoni, O. (1956). Prospero and Caliban, (P. Powesland, Trans.). London and New York: Praeger.

Miller, C. (1990). Theories of Africans: Francophone Literature and Anthropology in Africa. London and Chicago: Chicago University Press.

Moore-Gilbert, B. (1997). Postcolonial Theory: Contexts, Practices, Politics. London and New York: Verso.

Moore-Gilbert, B., Stanton, G., \& Maley, W. (Eds.). (1997). Postcolonial Criticism. London \& New York: Longman.

Msiska, M. (1997). East and Central African Writing. In M. Msiska \& P. Hyland (Eds.), Writing and Africa (pp. 46-65). London and New York: Longman.

Mullaney, J. (2010). Postcolonial Literatures in Context. London and New York: Continuum.

Nandy, A. (1983). The Intimate Enemy: Loss and Recovery of the Self under Colonialism. Delhi: Oxford University Press.

Neill, M. (1982). Guerrillas and Gangs: Frantz Fanon and V. S. Naipaul. Ariel, 13(4), 21-62.

Parry, B. (1994). Some Provisional Speculations on the Critique of "Resistance" Literature. In E. Boehmer, L. Chrisman, \& K. Parker (Eds.), Altered State? Writing and South Africa (pp.11-24). Sydney: Dangaroo Press.

Parry, B. (1996). Resistance Theory/Theorising Resistance or Two Cheers for Nativism. In P. Mongia (Ed.), Contemporary Postcolonial Theory: A Reader. London: Arnold.

Patil, A. (1995). Colonial and Post/Neo-colonial Discourse in Two Goan Novels: A Fanonian Study. Ariel, 26(4), $87-112$

Patke, R. S. (2001). Frantz Fanon. J. C. Hawley (Ed.). Encyclopedia of Postcolonial Studies (pp.162-167). Westport and London: Greenwood Press.

Ranger, T. (1968). Connexions between Primary Resistance Movements and Modern Mass Nationalism in East and Central Africa. Journal of African History, 9, (pp.437-453, pp.631-41).

Ranger, T. (1983). The Invention of Traditions in Colonial Africa. In E. Hobsbawm \& T. Ranger (Eds.), The Invention of Traditions (pp.211-62). Cambridge: Cambridge University Press.

Richards, C. S. (2005). Nationalism and the Development of Identity in Postcolonial Fiction: Zoë Wicomb and Michelle Cliff. Research in African Literatures, 36(1), 20-33. http://dx.doi.org/10.1353/ral.2005.0020

Sabbagh, S. (1982). Going Against the West from Within: The Emergence of the West as an Other in Frantz Fanon's Work, (Unpublished Doctoral Dissertation).University of Michigan. 
Said, E. (1994). Culture and Imperialism. London: Vintage.

Said, E. W. (1983). The World, the Text, and the Critic. Cambridge, MA: Harvard University Press.

Spivak, G. C. (1988). Can the Subaltern Speak? Speculations on Widow-Sacrifice. In C. Nelson, \& L. Grossberg (Eds.), Marxism and the Interpretation of Culture (pp.271-313). Basingstoke: Macmillan Education.

Tabuteau, E. (1993). Love in Black and White: A Comparative Study of Samuel Selvon and Frantz Fanon. Commonwealth, 16(2), 88-95.

Taylor, P. (1989). The Narrative of Liberation. Ithaca and London: Cornell University Press.

Thiong'o, N. (1972). Homecoming: Essays on African and Caribbean Literature, Culture and Politics. London: Heinemann.

Todorov, T. (1986). "Race", Writing, and Culture (L. Mack, Trans.). In H. L. Gates, Jr. (Ed.), "Race”, Writing, and Difference (pp.370-380). Chicago and London: The University of Chicago Press.

Valldejuli, L. G. (2007). Are We There Yet? The Tension Between Nativism and Humanism in Fanon's Writings. Human Architecture: Journal of the Sociology of Self Knowledge, V (Special Double Issue), 59-70.

Walder, D. (1998). Post-Colonial Literatures in English: History, Language, Theory. Oxford: Blackwell Publishers.

Williams, P., \& Chrisman, L. (1993). Introduction. In P. Williams, \& L. Chrisman (Eds.), Colonial Discourse and Post-Colonial Theory: A Reader (pp.1-20). London: Harvester/Wheatsheaf.

Young, R. (1990). White Mythologies: Writing History and the West. London and New York: Routledge. 